\title{
Socio-Cultural Aspects of the Film Adapted From Jaka Tarub Legend: Representation of the Image of Javanese Men
}

\author{
Nurhablisyah $^{1}$, Y Rukiah $^{2}$, D Pratama $^{3}$ \\ Faculty of Language and Art, Universitas Indraprasta PGRI, Jakarta Selatan, Indonesia ${ }^{1,2,3}$ \\ \{nurhablisyah@unindra.ac.id $\left.{ }^{1}\right\}$
}

\begin{abstract}
Jaka Tarub is one of the popular folklore in Java. The Story of Jaka Tarub, a man who's married to an angel is very popular in Java and other islands in Indonesia. Kalimantan, Lombok, and Madura each have a similar legend to Jaka Tarub. According to Babad Tanah Jawi, Jaka Tarub was believed as the ancestor of the Mataram Kingdom. He is the descendant of Syekh Maulana Magribi, the one who influences the Mataram kingdom with Islamic values. From Jaka Tarub was also known as Ki Ageng Tarub, is the ancestor of Islamic Mataram king. He got royal blood from Brawijaya King. Jaka Tarub was believed to have a certain power; he was married to angels, named Nawang Wulan. A man who could see married angels from khayangan was believed as powerful and extraordinary. He is also known for his hunting skill. This skill was lead him meeting his wife and having a magnificent story of life. In the "Jaka Tarub dan Tujuh Bidadari The Movie 1981", Jaka Tarub portrayed as the lowclass society and having a skin disease. He was being alienated by society because of his unknown father. In adaptation terminology, adaptation has several definitions; from repetition and variation to extended revisitations. Folklore adaptation into a movie was influenced by information of the source, language process, translation and many more. Jaka Tarub character was being captured and analyzed by a cultural studies approach. The research showed that Jaka Tarub represents the image of Javanese Men, who is the leader and protector of the family, responsible for taking care of family economic values and limited skill dealing with household chores.
\end{abstract}

Keywords: Adaptation, Jaka Tarub, Cultural, Javanese Men

\section{Introduction}

The Folklore of Jaka Tarub, a man who stole an angel's scarf in the river because he fell in love by the beauty of the angel and wants to have her love, is very popular among Javanese people. Jaka Tarub is not the only tale about a man who falls in love with an angel from Kahyangan. In Javanese mythology, Kahyangan was a place where angels and God's life. It could be located in the sky or paradise. Kahyangan was taken from the word 'Hyang" or gods. In this movie, Kahyangan was located in the sky, where the angels, god, and others who live there was immortal. The story of Awang Sukma and Tujuh Bidadari from South Kalimantan 
and the story of King Omas and Angels from North Sumatera are the example of stories that feature a similar plot and characters. Arya Menak and Putri Tunjung Sari from Madura, East Java also tells the same legend. In Ternate, there also exists a similar tale known as "Tujuh Putri Bidadari'[1].

Indonesia is not the only country that has a tale about a young man and angels. Japan also has a similar story. "Tanaba" is a legend of an ordinary man selling jugs. One day, after he sold the jug and passed by the lake, he saw beautiful angels having a bath there. He stole one of the angel's costumes, so one of them could not go back to the kingdom in the sky. The angel who was left out on Earth was called Tanaba. The young man then helps Tanaba by giving her proper clothes. Tanaba then fell in love with the guy and planned to marry him. But their marriage was prohibited by the kingdom in the sky and the guy's parent. Tanaba and her husband did the marriage, but the result, her husband was being moved out of the kingdom in the sky and drift away in Amanogawa's River [2].

Willian R. Bascom, folklore expertise, said that folklore has four functions: (1) A social projective system or reflection of social wishful thinking; (2) Folklore could be a tool to legalize social institution; (3). As a pedagogic system, and; (4) A tool to control the society [1]. Tales about angels are parts of folklore with solace stories. This kind of story was being told when mass media is unknown. People listen to the story while having dinner and gather with family. R.O Winstedt put staples about angels as folk romance. Folklore with solace stories or solace folks was described as stories which give happiness to the audience because it contains beautiful and happy moments[1]. As part of cultural heritages, Jaka Tarub folklore has particular values such as aesthetic, culture, unity, responsibility, and morality[3]. At the end of Jaka Tarub's story, NawangWulan left Jaka Tarub alone. He regretted his action and took good care of his one and only daughter, Nawangsih.

The story of Jaka Tarub has been adapted to many forms. One of them is "Jaka Tarub dan Tujuh Bidadari" the movie was produced in 1981 by PT. Young Bros Film and PT Interstudio. This movie was produced by HasanWijaya and Njoo Han Siang, directed by Bay Isbahi, and written by Tommy Burnama, Roy Andiar, and Bay Isbahi. In the movie, Jaka Tarub was pictured as a poor guy with a dark family background. His mother is an ordinary widow living in poverty. Jaka Tarub who has skin disease must fight their life by hunting animals in the wood. His religious background is animism and didn't relate to any major religion practiced in Indonesia. The movie didn't adapt Jaka Tarub'sfolklore fully, especially in describing Jaka Tarub's family background. This study will analyze the Movie "Jaka Tarub dan Tujuh Bidadari, 1981" focusing on the represent of Javanese man in Jaka Tarub'schacarters, by using Cultural Study approach.

\section{Method}

Movie or film is a medium to tell the story. At the beginning of its development, the movie was used to record events and certain actions for watching consumption. In the past, the movie is considered a ground-breaking, newest, and unique technology. From 1986 to 1901, scenario or screenplay for the movie was written in synopsis format or not longer than one paragraph. However, after 1901, the duration of the movie is getting longer. People have more demand for an enjoyable movie. Thus, the way to produce and write stories are getting complicated [4]

The movie appearance could not be separated from human's desire to seek happiness and fulfill their desire. Adi (2011) explained that this concept was part of Sigmund Freud's opinion, where a psychological object is considered as reality. Through documentary, the film shows how a man tried to draw reality into a movie. For moviemaker, this psychological 
motive drives them to create [5]. A movie is considered qualified if it has good content and well packaged. The advantages of a drama movie are the level of sensitivity and honesty in portraying logical human living in society. Octaviani \& Nugroho (2016) thought that drama would be more interesting when reflecting man's problem through dreams, demands, though, and reaction [6].

Generally, the drama movie tends to focus on the protagonist character [6]. Isnaadi\&Setiawatidefined protagonist character as a central character in the movie who controls the scene's transition [7]. The character is one of important thing in developing a story. The character is described as someone who acts in the story [8]. Sayuti says the main character is someone who most connects to the meaning and theme of the story [8]. In every story, a character not only shown up by the physical attraction but also attitudes, dialogue, and way of thinking. Every character should be accepted clearly to the audience to understand the story.

Aristo and Ash Shiddiq define story as a chain of occurrence where the main character was involved[4]. The occurrence is described as facts in a certain space and time. The characters are the subject and object in the occurrence. Stories as literature or film are part of the culture; they have limits and rules. The main character is someone who wants to catch his or her dreams. He will face heavy obstacles to achieve the desired results.

Jaka Tarub's character was analyzed by using Cultural Study approach. Jaka Tarub was the descent of Seh Maulana Magribi and Prabu Brawijaya. Barthes in Cavallaro [9] explained how the cultural phenomenon was analyzed by using denotation and connotation concept. Denotation is how descriptive meaning is visually and owned by cultural members. The connotation is represented by relating the denotation with wider cultural aspects as; faith, behavior, framework, and ideology. The movie, Jaka Tarub was portrayed as the low-class society. This was visually showed by the Jaka Tarub's costume, his house in the middle of the wood, he was hunting animals to survive, he got skin disease and alienated by society. He was struggling and almost gave up because no girls want to be his wife. The connotation aspects in the movie were shows by Jaka Tarub's character such as how he deals with his mother and wife.

Adaptation is something that repetitive and has a lot of variations. Hutcheon in Cavallaro (2010) [9] explained adaptation as a process of announcing or deliberating ideas with not just imitation. Julie Sanders says adaptation as something that is coming back with a different form. Meanwhile, Linda Costanzo Cahir, describe adaptation as "translation." Adaptation is being divided into three levels by John M. Desmond, "close, loose, and intermediate." In "Jaka Tarub dan Tujuh Bidadari the Movie 1981" the story of the movie was adapted from "The Old babad Tanah Jawi." Jaka Tarub as the main character was comes from an ordinary family. He was living in the wood with his mother, because of his unknown father. Jaka Tarub is a legend from West Java, who's quite popular. But when he was described with a different background, it would lead into a different action. In Javanese feudalism concept, the royal family has higher social status and being respected by the society. Royal family and their heirs got an extra treatment such; skill, power, visually personable and well manner. In Javanese tradition, a man or a husband mostly become the leader of the family and having legitimate power to make a decision in the family. This study would analyse how Javanese man is represented in the movie. 


\section{Result and discussion}

Jaka Tarub plays an important role as the ancestor of Mataram Kingdom. His daughter, Nawangsih married to Lembu Peteng, the Son of Brawijaya King, the King of Majapahit. Javanese cultural is known for bibit, bebet, bobot when seeking for bride and grooms. As an ancestor of Mataram Kingdom, Jaka Tarub would be fulfilling the Bibit, bebet, boot for ideal Javanese leader. In the other hand, his behaviour, stealing the scarf of Nawangwulan is not acceptable. It was not being part of a gentleman. But many story has the same plot and character as Jaka Tarub.

\section{Conclusion}

There are two versions which tell about Jaka Tarub family [2]. In Old Babad Tanah Jawa, Jaka Tarub was told as a son from an ordinary people. But in Babad Tanah Demak (latest version of Babad Tanah Jawa), Jaka Tarub is a son of Syeh Maulana Magribi which have strong relation with Brawijaya King. The recent Babad Tanah Jawa were trying to legitimate Jaka Tarub's position as royal's family. Legitimation's effort could be seen in social status's changing and the character's supernatural powers. Jaka Tarub's parent in Old Babad Tanah Jawa was known as Sang Raradan Ki Jaka. But in newest version become Dewi Rasawulan and Syeh Maulana Magribi.

How Jaka Tarub being portrayed in this film is having a distance to the folklore in Java and other Islands. Even though in Babad Tanah Jawa old version, it didn't mention about skin disease and alienation. Jaka Tarub was believed having a connection with Hindu and Islam, but that didn't mention in the movie. As an ancestor of a royal family, he should represent humble, gentle and wise behavior. But Jaka Tarub portrayed contrary. The facts that similar story spread around the island in Indonesia, giving another conclusion, could be the story represent man's behavior toward a woman in order to attract a woman's heart. Robi in Wibowo [2] found that it is possible Jaka Tarub's Story and Tanaba have the same characters, plot and setting even though Indonesia and Japan located in the far distance. According to Lévi-Strauss [2], the similarity of the story (in Indonesia and Japan), is the result of the mechanism of human's mind. Even though myths and legends are part of human's creations, but those expressions appear on a certain structural way.

As Hutcheon in Cavallaro [9] said that adaptation is not just imitating the story and announcing to the public. Producer or writer could put their subjective perspective in the movie. In 1980's movie industry in Indonesia was developing. There is plenty of house production which produces a movie and played it cinema. The genre of the movie was also varied, from romantic drama, horror, and action in that era. The history of Indonesian movie was connected to China and India businessman whose trading in ancient time. Movie was brought to Indonesia through trading and colonialism. In that era, Indonesia was facing "Orde Baru" period. In this time, Indonesia has a massive infrastructure and industrial development. The government is focusing on raising human resource by opening the source of information. But, not all the source of information was unlocking freely. Government still regulated mass media and the message. Mostly, any kind of information that could harm the stability of defense was forbidden. This policy tends media to giving information carefully and avoiding sensitive issues as power, authority, religious, government's regulation, etc.

In Cultural Studies perspective, especially Andorno and Horkheim (1979) in Barker [10] mentioned that cultural products are commodities produced by cultural industries. Even 
though the industries are part of democratization, individualist and vary, but in reality these commodities are authoritarian, conformity and fully standardized. Film, Radio, and magazine create a system to produce. Fiske (1989) included film as part of popular culture. The meaning of popular culture is created by moviemaker rather than identified with text. Fiske focused on the vitality, and popular creativity was made to a social changing. Fiske also noted that in capitalism, there's no authentic cultural in non-authentic society.

The disparity between "Jaka Tarub and Seven Angels The Movie" and the folklore could happen. The producer of the film was adapted to their perspective. Jaka Tarub is described as a poor man with a disease. His family background was not a royal family. Jaka Tarub was facing by difficult living in the movie. This idea made the conflict of the plot more complicated compare if Jaka Tarub comes from royal progeny. More conflict was needed to create tend in the story. Therefore, skin disease has become the other obstacle in Jaka Tarub's life, how he overcome reality and looking for a bride. Jaka Tarub has to work hard to change his life, but destiny and fortune also play an important role in life. How Jaka Tarub got his fortune, the movie portrayed him as an obedient and loving son to his mother.

Religious background was not mentioned in the movie; it considered as inappropriate that could lead critics in society. There is a lot of question relate to the religious character of Jaka Tarub. Why a man with religious background was peeping angels while they had a bath? Why he stole the Nawang Wulan's scarf in order to have her as a wife? Why Jaka Tarub lied to the one, he loved?. Portraying Jaka Tarub with his religious believed considered as not necessary, especially if it has the possibility of controversy. In the movie, Jaka Tarub was an ordinary man, but NawangWulan was comes from Kahyangan. Even though Jaka Tarub is the leader of the family, he has limited power over NawangWulan. When his wife ask him to cook the rice, Jaka Tarub didn't' follow his wife instruction. As a leader in the family, a man not just carried the responsibility to fulfilling the family's needs, but he was also a role models. When Jaka Tarub left by his wife, Jaka Tarub ask NawangWulan to consider her decision. But his wife deny to continued living with him. He regret and feel ashamed for lying to his loved one. The movie showed the soreness that Jaka Tarub's endured. But he realized this would happened, he ask for apologized and accepted his faith.

\section{References}

[1] P. G. Yanti, Sukardi, and U. Qura, "Muatan Budaya Dalam Dongeng Bidadari," in Bahasa, Sastra, dan Nasionalisme, 2014, p. 48.

[2] R. Wibowo, "Jaka Tarub dan Tanabata: Kajian Strukturalisme Levi-Strauss,” 2013.

[3] R. A. Saputri, "Nilai-Nilai Yang Terkandung dalam Cerita Rakyat 'Jaka Tarub' di Daerah Jawa Tengah," J. Bastra, vol. 1, no. 1, p. 15, 2016.

[4] S. Aristo and A. Ash Shiddiq, Kelas Skenario Wujudkan Ide Menjadi Naskah Film. Jakarta: Erlangga, 2018.

[5] A. A. Erdina, "Dokumenteranimasi Sebuah Wacana Visual," Capture J. Seni Mediarekam, vol. 2, no. 2, pp. 6-14, 2011.

[6] O. D. Dyah and N. Sugeng, "Pola Karya Konvensi Pada Film Sekuel Studi Kasus Film Ada Apa Dengan Cinta?2," J. Kaji. Seni, vol. 3, no. 1, pp. 81-94, 2016.

[7] M. A. Isnaadi and S. W. Setiawati, "Keherensi Antar Cerita Dalam Penyutradaraan Drama Lepas Sabtu Sore Bercerita," Capture J. Seni Media Rekam, vol. 7, no. 2, pp. 60-70, 2016.

[8] P. F. Putra, "Penokohan dan Perwatakan Tokoh Novel Bumi Cinta Karya Habiburahman El Shirazy," Universitas Bengkulu, 2014. 
[9] C. Dani, Anime and the visual novel: narrative structure, design and play at the crossroads of animation and computer games. Jefferson: Mcfarland \& Company, 2010.

[10] B. Chris, Cultural Studies Teori dan Praktik. Jakarta: Kreasi Wacana, 2015. 